\title{
DEVELOPMENT OF POSTGRADUATE EDUCATION OF DOCTORS IN THE CONTEXT OF THE HEALTH CARE SYSTEM REFORMING IN UKRAINE
}

\author{
Hretta Hukova-Kushnir

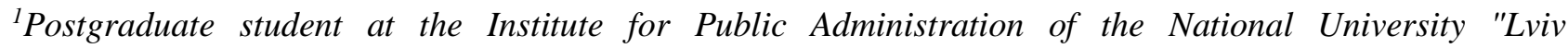 \\ Polytechnic", Lviv, Ukraine, e-mail: gretta33544@gmail.com
}

\begin{abstract}
The reform of the financing of the healthcare system, launched in 2017, which led to a change in the number and functional responsibilities of medical staff, is analysed in the article. The purpose of the article is to systematize and analyse the regulatory framework, according to which the regulation of a comprehensive system of postgraduate education of doctors at the present stage and determines the prospects for its development. The method of studying the problems of changes in the health care system in the field of postgraduate education of doctors in Ukraine is determined: methods of theoretical analysis (studying the content of health care system reform and decision making in unpredictable results), analogies, study of current regulations, as well as those coming into force in January 2022 from open official sources of information (we will rely on official data of government agencies and international organizations), statistical analysis, situational modelling (to predict change). An analysis of current regulations on the development of postgraduate education of doctors in Ukraine was conducted, which made it possible to identify problem areas in this area. It is substantiated that due to the lack of an effective methodology for assessing the training needs of health professionals, higher education institutions, taking advantage of high market demand, seek to maximize the number of contract students without considering the level of training and needs of the state. Accordingly, any long-term forecasting will need to be adjusted. Changes in the legislation concerning internships and secondary medical (pharmacy) specialties have undergone significant changes. Reducing the duration of practical training can negatively affect the quality of training of narrow specialists. Complicating the process of admission to the secondary medical (pharmacy) specialization will lead to a decrease in those wishing to obtain it and therefore reduce the number of narrow specialists. As a result, all this may lead to a deterioration in the quality of medical services in Ukraine.
\end{abstract}

Keywords: health care; strategy of medical education development; state policy in the field of health care; medical specialization; pharmacy; continuous professional training of doctors.

JEL Classification: A23, I20, I21

Formulas:0; fig.0; tabl. 0; bibl. 30

Introduction. The proclamation of Ukraine's course for European integration has raised the issue of changing approaches to medical education in general and improving the quality of training of future doctors in particular.

The main objective function and at the same time the criterion of the health care system at any stage of its development is the quality of medical care. Quality assurance in health care is seen in most countries as a cornerstone of national health policy. The quality of professional functions directly affects the quality of life and health of people who are recognized as the highest social values in Ukraine and around the world. That is why in many countries, health professions have the status of regulated, and all stages of vocational training are mandatory and controlled by the state.

The national health care system is currently looking for ways out of the crisis, which is due to various factors. On the one hand, there is a decrease in the prestige of the medical profession, resulting in insufficient motivation of graduates of higher 
education to work in the specialty, threatening the medical industry external migration of doctors and other health workers (job search abroad), and changing occupations outside the medical field.

On the other hand, innovative technologies and evidence-based medicine are rapidly developing, new methods of treatment and diagnosis of diseases, the latest information and modern telemedicine technologies are being introduced into the practice of health care institutions. This allows you to develop and work in a single professional world or European space but requires intensified measures to reform the health education system. Therefore, the formation of a new model of education, close to world and European standards, will strengthen the competitiveness of domestic higher medical education, optimize conditions for international mobility and empowerment of Ukrainian medical professionals in domestic and international labour markets, strengthen motivation of professionals to stay in Ukraine and provide medical services.

Literature Review. The article uses literature of a normative nature and some research in the field of public administration. We used the regulatory legal acts of the Ministry of Health of Ukraine, the Cabinet of Ministers of Ukraine, namely Resolution of the Cabinet of Ministers of Ukraine, Order of the Ministry of Health of Ukraine, which regulate management in the field of the health care system and relate to the subject of the study. And also used the research of Ukrainian scientists in the theory and practice of the competence approach to management and reforming the system of state administration [2-5].

Aims. The purpose of the article is to systematize and analyse the regulatory framework, according to which the regulation of a comprehensive system of postgraduate education of doctors at the present stage and determines the prospects for its development.

Methods.The method of studying the problems of changes in the health care system in the field of postgraduate education of doctors in Ukraine is determined: methods of theoretical analysis (studying the content of health care system reform and decision making in unpredictable results), analogies, study of current regulations, as well as those coming into force in January 2022 from open official sources of information (we will rely on official data of government agencies and international organizations), statistical analysis, situational modelling (to predict change).

Results.Ukraine has a well-developed network of institutions of higher medical education of various levels of accreditation, which trains specialists for the needs of domestic health care, as well as specialists for other countries. There are 14 public and 5 private medical universities in Ukraine. Also, three institutions of postgraduate education are subordinated to the Ministry of Health. More than 150,000 Ukrainian citizens study medical specialties in the Ukrainian higher education system, most of whom study at universities under the Ministry of Health of Ukraine) [8].

However, taking into account international experience, it can be noted that the number of graduates of medical specialties remains relatively high. For example, the number of graduates in Ukraine in 2015 was much higher than in the United States 
and Canada. Thus, in Ukraine there are 230 graduates per 1 million population, in Canada - 122, and in the United States - 58.

Such high quantitative indicators of training of future doctors not only do not correlate with the quality of medical care, but also raise concerns about the need to train such a large number of specialists in relevant specialties. As of today, there is no effective system for forecasting the need for medical staff, and the existing registers of medical workers do not reflect the real picture. The Ministry of Health informs about the low level of preparation of students, which is confirmed by the results of the license exams "Step". With a passing score of 60.5\% (Step 2) and 70.5\% (Step 3), about $10 \%$ of medical students each year cannot overcome the passing barrier [1].

The results of the comparative study showed that it is necessary to increase the requirements for the content and quality of training of interns at all stages of the internship, which requires reform of the internship: approval of the new Regulations on internships, and computer programs for attestation of interns in accordance with modern treatment protocols and diagnostic standards [7]. To build a quality system of medical education in Ukraine, in order to ensure the health of health professionals with a high level of training, the Government of Ukraine has developed and adopted a Strategy for the development of medical education in Ukraine, which is designed for 10 years [10]. As a result of the implementation of the strategy for the development of medical education, approaches to the formation of the system of postgraduate education and its content must change qualitatively. The practical implementation of the Strategy began with significant changes in the regulatory and legal support of postgraduate education at all stages of its receipt.

At the first stage, legislative changes took place before the internship (primary medical specialization). Internship is one of the stages of training a doctor, which is mandatory for the title of "specialist doctor" or "pharmacist specialist" and further employment as a specialist doctor (pharmacist specialist) in the specialty. Internship is a form of postgraduate training of graduates in medical and pharmacy specialties, the main task of which is to increase the level of practical and theoretical training of doctors (pharmacists) -interns, their professional readiness for independent activity in the specialty.

After completing the sixth year of medical school and successfully passing the Unified State Qualification Exam, a medical student must undergo practical training in a health care institution. If until now the internship was regulated by two orders of the Ministry of Health of Ukraine [13], [14], then from January 1, 2022, these regulations expire and a new order of the Ministry of Health of Ukraine from 22.06.2021 № 1254 [15].

The internship program forms a single set of educational and practical components, planned and organized by higher education institutions and internship bases of doctors (pharmacists) -interns to ensure the acquisition by doctors (pharmacists) -interns of competencies required to qualify as a specialist or pharmacist-specialist which is based on academic integrity, medical and pharmaceutical ethics and deontology, evidence-based medicine.

The new model will provide for the introduction of a fair distribution of internships and standardization of its content provides: 
- reducing the number of medical specialties in the internship;

- change of requirements to bases of passing of internship;

- change of the internship financing system;

- creation of a national ranking of students according to objective independent evaluation criteria based, in particular, on the academic performance of students;

- creation of a national register of internships with places of internship by specialties and bases of passing;

- development of software for objective and transparent distribution of internship places on the basis of rating;

- development of mechanisms for the introduction of academic mobility of interns;

- development of mechanisms for evaluating the effectiveness of internships.

According to the new requirements, the number of basic specialties in the internship decreased by 9 positions. Thus, such specialties as general hygiene, clinical oncology, neurosurgery, pulmonology and tuberculosis, forensic examination, urology, neonatology, sports medicine and paediatric otolaryngology are classified as secondary specialization. It is also necessary to note some differences in paediatricanaesthesiology: it is not included in the list of basic specializations but is in the list of those specialties based on which the secondary specialization takes place.

Thus, the list of secondary medical (pharmacy) specialties has changed, as well as the procedure for admission to them and the terms of training. For example, training in the internship in "Neurosurgery" under the new legislation is not carried out, instead there is a secondary medical specialization "Neurosurgery", which lasts 9 months and admission to which is possible only in the primary specialty (internship) "Surgery", training in which it lasts 3 years. That is, in today's reality to become a neurosurgeon, it takes 3 years and 9 months, of which 3 years - general surgery and 9 months of neurosurgery, in contrast to the previous legislation - 3 years of neurosurgery. This means that the period of practice in a narrow specialty is reduced from 3 years to 9 months.

Currently, there is a significant difference between the number of years of training for doctors in Ukraine and in the world. For example, in the United States, the training of obstetricians and gynaecologists lasts 12 years, while in Ukraine - 9. This is an irrelevant experience and makes it impossible to compete with Ukrainian specialists at the global level.

Now students of various specialties undergo internships from one to three years. The internship program consists of two parts: educational, which is conducted in a higher education institution that trains doctors (pharmacists) -interns lasting three months for one year of study, and practical, which is conducted based on internships for doctors (pharmacists) -interns.

Secondary medical specialization - acquisition by a doctor of a specialty not provided for internship training, is carried out in accordance with the Regulations on postgraduate training of doctors (pharmacists), approved by the Ministry of Health of Ukraine [12], and provides certification to determine knowledge and practical skills the title of specialist in the relevant specialty. 
Enrolment in the internship is based on the results of rating distribution - a system of electronic distribution of graduates of higher education institutions in the internship, which collects and analyses data on the success of graduates and provides automated rating distribution [18-22]. The order of rating distribution is carried out based on the competitive score received by the graduate. Rating distribution is mandatory for admission to the internship at the expense of the state budget and is conducted for graduates:

- who studied at a higher education institution by state order

- who studied in a higher education institution at the expense of individuals (legal entities).

The ranking lists are published in full on the official website of the higher education institution. According to the results of the rating distribution, the higher education institution issues a referral to the graduate to undergo an internship training program.

In the second stage, a residency will be introduced for doctors who want to gain deeper knowledge in the medical field. The introduction of medical residency is planned to be carried out by:

- conducting a study of the optimal model of medical residency;

- regulatory regulation (determination of the list of specialties, duration of training);

- determination of requirements for medical residency;

- introduction of a new medical residency, which will be held at the place of employment of the resident;

- mutual recognition of medical residency with EU member states.

At the third stage, the outdated system of professional development in accordance with the Resolution of the Cabinet of Ministers of Ukraine [11] is transformed into a system of continuous professional development of doctors.

Ensuring continuous professional development, based on best international practices, is expected to be done by:

- definition of requirements to providers of continuous professional development;

- granting medical workers, the right to independently choose the place of training;

- changes in the model of financing continuous professional development (introduction of a model according to which the state will allocate funds for training of each doctor).

Continuing professional development of health professionals is a continuous process of training and improving the professional competencies of professionals after obtaining higher education in health care and postgraduate education in internships [23-30]. This will allow the professional to maintain or improve the standards of professional activity in accordance with the needs of health care and will continue throughout the period of professional activity.

Discussion. The new system of continuous professional development will ensure proper quality control of certification of specialists in the field of knowledge "Health" and improve the quality of medical care for Ukrainians [6]. The doctor must study every year. He decides personally where to do it and what skills to improve. According to the new model, there should be a demonopolization of education: now 
the choice of place or organization goes to the doctor. Recognized: education received abroad, participation in professional seminars and conferences, online courses, workshops and more.

In the future, it is planned that the Ukrainian medical student will have as many years of training as their colleagues abroad [12].

Conclusions. Analysis of the legal mechanism of postgraduate education of doctors made it possible to identify problem areas in this area. The reform of the financing of the health care system, launched in 2017, leads to a change in the number and functional responsibilities of medical staff. Accordingly, any long-term forecasting will need to be adjusted.

Due to the lack of an effective methodology for assessing the training needs of health workers, higher education institutions, taking advantage of high market demand, seek to maximize the number of contract students without taking into account the level of training of entrants and the needs of the state.

The level of communication between higher education institutions (faculties), health care institutions and executive bodies is low. Institutions of higher education (faculties) do not participate in the process of making managerial decisions regarding the development of medical education.

Changes in the legislation concerning internships and secondary medical (pharmacy) specialties have undergone significant changes. Reducing the duration of practical training can negatively affect the quality of training of narrow specialists. Complicating the process of admission to the secondary medical (pharmacy) specialization will lead to a decrease in those wishing to obtain it and as a consequence reduce the number of narrow specialists. As a result, all this will lead to a deterioration in the quality of medical services in Ukraine.

\section{References:}

1. Current state and prospects of medical education in Ukraine. URL: http://nbuviap.gov.ua/index.php?option=com_content\&view=article\&id=2855:suchasnij-stan-ta-perspektivi-rozvitkumedichnoji-osviti-v -ukraine\&catid $=8$ \&Itemid $=350$

2. Karpa, M. (2021). The competence of the executive authorities of Ukraine in the field of healthcare and national security to eliminate the consequences of coronavirus disease (Covid-19). Karpa M., Akimov O. Public Administration and Law Review, Issue 1 (5), 2021, pp. 73-82. https://doi.org/10.36690/2674-5216-2021-1.

3. Karpa, M. (2021). Universally recognized and national principles of competence of civil servants as a basis for legal provision of information security: the experience of the European Union. Journal of interdisciplinary research (11(2)). pp. 48-53.

4. Karpa, M. Akimov, O. (2021). Competence Approach to the Development of Modern Public Administration: Theory and Practice of Implementation. International Conference on Economics, Law and Education Research (ELER 2021. pp. 40-45. doi: https://doi.org/10.2991/aebmr.k.210320.008

5. Khudoba, O. (2019). Staff Training As A Tool For Managing Social Relations: Adaptive Approach In The Context Of The Dementia Problem. Public Administration and Regional Development, (5), 602-621.

6. Reform of medical education: what will change for students and doctors. Official website of the Ministry of Health of Ukraine. URL: https://moz.gov.ua/article/reform-plan/reforma-medichnoi-osviti-scho-zminitsja-dlja-studentiv-talikariv-

7. Results of a comparative study of the quality of medical education in Ukraine at the postgraduate stage of training of doctors. Official website of the Ministry of Health of Ukraine. URL: https://moz.gov.ua/article/news/rezultatiporivnjalnogo-doslidzhennja-jakosti-medichnoi-osviti-v-ukraini-na-pisljadiplomnomu -staps-preparations-likariv-

8. Strategy for the development of medical education in Ukraine. Official website of the Ministry of Health of Ukraine. URL: https://moz.gov.ua/uploads/1/8475-medical_education_analytics.pdf.

9. The Cabinet of Ministers of Ukraine (2018). On approval of the Regulations on the system of continuous professional development of specialists in the field of health care: Resolution, March 28, 2018 №302. URL: https://zakon.rada.gov.ua/laws/show/z0113-93\#Text. 
10. The Cabinet of Ministers of Ukraine (2019). On approval of the Strategy for the development of medical education in Ukraine: Order, 27.02.2019 № 95-r. URL: https://zakon.rada.gov.ua/laws/show/95-2019-\%D1\%80\# Text.

11. The Cabinet of Ministers of Ukraine On approval of the Regulations on the system of continuous professional development of medical and pharmaceutical workers: Resolution, 14.07.2021 № 725 . URL: https://zakon.rada.gov.ua/laws/show/725-2021-p\#Text.

12. The Ministry of Health of Ukraine (1993). On further improvement of the system of postgraduate training of doctors (pharmacists): Order, 27.07.1993 № 166. URL: https://zakon.rada.gov.ua/laws/show/z0113-93\#Text.

13. The Ministry of Health of Ukraine (1996). On approval of the Regulations on specialization (internship) of graduates of higher medical and pharmaceutical educational institutions of III-IV level of accreditation of medical faculties of universities: Order, 19.09.1996 № 291. URL: https://zakon.rada.gov.ua/ laws / show / z0696-96 \# Text.

14. The Ministry of Health of Ukraine (2005). On approval of the List of specialties and terms of study in the internship of graduates of medical and pharmaceutical higher educational institutions, medical faculties of universities: Order, 23.02.2005 № 81. URL: https://zakononline.com.ua/documents/show/101105_531820.

15. The Ministry of Health of Ukraine (2021). On approval of the Regulations on internship and secondary medical (pharmacy) specialization: Order, 22.06.2021 № 1254. URL: https://moz.gov.ua/article/ministry-mandates/nakaz-mozukraini-vid -22062021--1254-pro-zatverdzhennja-polozhennja-pro-internaturu-ta-vtorinnu-likarsku-provizorskuspecializacija.

16. The Ministry of Health of Ukraine is changing the approach to the training of doctors: public discussion of the new internship model. URL: https://moz.gov.ua/article/news/moz-ukraini-zminjue-pidhid-do-pidgotovki-likariv-gromadskeobgovorennja-novoi -model internships.

17. Ukraine needs reform of medical education. URL: https://osvita.ua/vnz/54789/.

18. Karpa, M. (2021). Features of introduction of the system approach to the state policy. Karpa M., Akimov O. Public Administration and Law Review, Features of introduction of the system approch to the state policy . Karpa, M., Akimov, O., \& Akimova, L. Public Administration and Law Review, (3), pp. 11-17. https://doi.org/10.36690/26745216-2021-3-11.

19. Karpa, M. (2020). Implementation of innovative forms and models of public administration in the sphere of culture in Ukraine / Karpa, M., O. Akimov, and V. Shykerynets / Karpa, M., O. Akimov, and V. Shykerynets / Public Administration and Law Review, no. 3, Oct. 2020, pp. 13-24, doi:10.36690/2674-5216-2020-3-13.

20. Gupta, S.K., Alareeni, B., Karpa, M.I., Umrao, L.S., \& Gupta, M. (2021). Detection of Fake News Problems and Their Evaluation Through Artificial Intelligence. Lecture Notes in Networks and Systems, 2021, 194 LNNS. pp. 94-101. 21. Mlaabdal, S., Chygryn, O., Kwilinski, A., Muzychuk, O., \& Akimov, O. (2020) Economic Growth and Oil Industry Development: Assessment of the Interaction of National Economy Indicators. Proceedings of the 36th International Business Information Management Association (IBIMA). pp. 8102-8114.

22. Gupta, M., Alareeni, B., Akimova, L., Gupta, S.K., \& Derhaliuk, M.O. (2021) Application of Fuzzy Logic Data Analysis Method for Business Development. Lecture Notes in Networks and Systems, 2021, 194 LNNS. pp. 75-93.

23. Pustova, N. and Akimov, O. (2021), Child labor and public administration policy against its use, Investytsiyi: praktyka ta dosvid, vol. 20, pp. 81-86. DOI: 10.32702/2306-6814.2021.20.81.

24. Akimov, O. (2020), Systemogenesis of personal competences in psychogenic measurement, Investytsiyi: praktyka ta dosvid, vol. 5-6, pp. 81-88. DOI: 10.32702/2306-6814.2020.5-6.81.

25. Akimov, O. (2020), Substantiation of the paradigm of the systemogenesis of public administration, Investytsiyi: praktyka ta dosvid, vol. 4, pp. 86-92. DOI: 10.32702/2306-6814.2020.4.86.

26. Akimov, O. (2020), Tendencies of development of public-service activity as the bases of the paradigm of the systemogenesis of public administration, Investytsiyi: praktyka ta dosvid, vol. 3, pp. 135-142. DOI: 10.32702/23066814.2020.3.135.

27. Akimov, O. (2019), System-genesis approach to the implementation of public administration in Ukraine: problems of formation, Investytsiyi: praktyka ta dosvid, vol. 21, pp. 90-95. DOI: 10.32702/2306-6814.2019.21.90.

28. Akimov, O. (2019), The robustness of the system of professional activity of public employees: systemogenescial context, Investytsiyi: praktyka ta dosvid, vol. 5, pp. 104-109. DOI: 10.32702/2306-6814.2019.5.104.

29. Akimov, O. (2018), Functional factors of the system genesis of the professional activities of civil servants, Investytsiyi: praktyka ta dosvid, vol. 24, pp. 68-74. DOI: 10.32702/2306-6814.2018.24.68.

30. Akimov, O. (2018), The concept of the system genesis of the professional activities of public servants, Investytsiyi: praktyka ta dosvid, vol. 23, pp. 133-138. DOI: 10.32702/2306-6814.2018.23.133.

Received: November 15, 2021 Approved: December 24, 2021 